\title{
PENERAPAN SISTEM KEUANGAN DESA (SISKEUDES) PADA ORGANISASI PEMERINTAHAN DESA (STUDI KASUS DI DESA SUWAAN KECAMATAN KALAWAT KABUPATEN MINAHASA UTARA)
}

\author{
Jehan M. Malahika ${ }^{1}$, Herman Karamoy ${ }^{2}$, Rudy J. Pusung ${ }^{3}$ \\ 1,2,3 Fakultas Ekonomi dan Bisnis, Jurusan Akuntansi, Universitas Sam Ratulangi, Jl. Kampus Bahu, Manado, \\ 95115, Indonesia \\ E-mail : jehanmalahika@gmail.com
}

\begin{abstract}
This research aims to analyze the Implementation of Village Financial System (SISKEUDES) towards the government organization in Suwaan Village Kalawat Subdistrict North Minahasa Regency. This research using qualitative research approach as using primary data, which were in the form of interview and secondary data. The informants are the village head, the village secretaries, and the head of village government affairs. The result showed that : (1) The implementation of Village Financial System in Suwaan Village has running well (2) The procedure of SISKEUDES utilization done by 4 stages which are : Planning, Implementing, Administrating, and Reporting (3) Village Financial System has been giving the positive influence towards the performance of each employee. Therefore, Village Financial System holds an important role upon village government that impact directly by the employee of village. This is as accordance with the purpose on the implementation of Village Financing System which is to assist the work of villagers' employee.
\end{abstract}

Keywords: Village Financial System, Village Government

\section{PENDAHULUAN}

Desa adalah suatu daerah yang paling kecil diantara tingkatan susunan suatu negara, berbeda dengan kota desa terdiri dari beberapa aspek-aspek kecil kumpulan masyarakat yang mendukung berkembangnya suatu pemerintahan negara. Pada saat perkembangan daerah di mulai desa-desa sudah di berikan kekuasaan untuk mengelola menjadi mandiri dalam mengelola keuangan dan melaksanakan pemerintahan untuk pembangunan desa yang lebih baik. Setiap desa diberikan kebebasan dalam meyusun laporan keuangan. Laporan keuangan yang nantinya dibuat oleh pemerintah desa dan menyediakan informasi yang dapat digunakan sebagai pedoman menyusun anggaran pada tahun selanjutnya.

Laporan keuangan ada dan disusun untuk menyediakan informasi yang efektif dan relevan mengenai transaksi keuangan dan seluruh kegiatan ekonomi yang dilakukan oleh sebuah entitas pelaporan. Seiring dengan reformasi dibidang keuangan negara, maka perlu dilakukan perubahan diberbagai bidang keuangan negara agar dapat berjalan dengan baik. Salah satu perubahan yang signifikan adalah perubahan dibidang akuntansi pemerintah karena melalui proses akuntansi dihasillkan informasi keuangan yang tersedia berbagai pihak untuk digunakan sesuai dengan tujuan masing-masing. Pengelolaan keuangan desa harus dilakuknan dengan baik agar tidak terjadi kecurangan-kecurangan dalam mengelolan anggaran desa. Untuk membantu pemerintah desa dalam mengelola keuangan desa, Badan Pengawas Keuangan Keuangan dan Pembangunan (BPKP) membuat suatu aplikasi yang bertujuan untuk meningkatkan mutu dan kualitas tata kelola keuangan desa. Aplikasi yang dimaksud adalah Aplikasi Sistem Keuangan Desa (SISKEUDES). Pemerintah dalam mengembangkan SISKEUDES adalah untuk membantu pemerintah desa lebih mandiri dalam mengelola keuangan desa secara efektif dan lebih baik, serta meningkatkan transparansi dalam akuntabilitas keuangan di desa. Dengan adanya SISKEUDES diharapkan pemerintah 
desa lebih mandiri dan lebih bekerja keras dalam mengelola unsur pemerintahan dan sumber daya alam yang dimiliki. Aplikasi ini dikeluarkan BPKP pada tahun 2016 dan sudah mulai diterapkan di desa-desa. Di mulai pada tahun 2016 tentunya banyak kendala-kendala yang dihadapi terhadap penerapannya dan bagaimana pemerintah desa melakukan persiapan untuk penggunaan aplikasi ini.

\section{TINJAUAN PUSTAKA}

Pengertian Akuntansi. Akuntansi adalah suatu sistem dan informasi mengenai sesuatu atau kejadian yang timbul dari hasil adanya suatu transaksi ekonomi yang menyediakan keputusan-keputusan yang bijak mengenai suatu posisi keuangan.

Akuntansi Sektor Publik. Akuntansi sektor publik adalah suatu aktivitas dalam bidang publik yang menyediakan suatu bentuk laporan yang terjadi karena adanya transaksi ekonomi atau kegiatan mencatat yang menimbulkan adanya suatu laporan untuk mempertanggungjawabkan keuangan di bidang publik.

Pemerintah Desa. Pemerintah desa merupakan simbol formal dari keseluruhan masyarakat desa yang mengatur pelaksanaan kegiatan-kegiatan dan urusan pemerintahan oleh di desa dan badan permusyawaratan yang di pilih oleh masyarakat dan untuk kepentingan masyarakat.

Pengelolaan Keuangan Desa. Pengelolaan keuangan desa adalah suatu bentuk tahap atau proses dalam mengelola keuangan desa yang terdiri dari 4 tahap yaitu perencanaan, pelaksanaan, penatausahaan dan pelaporan keuangan desa.

Perencanaan. Perencanaan merupakan tahap perumusan program/kegiatan yang akan dilaksanakan pada desa yang bersangkutan. Pemerintah desa melakukan perencanaan dalam rangka pembangunan desa yang sesuai dengan kewenangannya.

Pelaksanaan. Pelaksanaan keuangan desa merupakan kegiatan dari proses perencanaan yang sudah ada dan kemudian pertahap-pertahap dilaksanakan dalam proses pembangunan desa. Untuk mencapai target pelaksanaan harus dilaksanakan dengan baik.

Penatausahaan. Penatausahaan keuangan desa merupakan suatu kegiatan pada tahap ini proses penataushaan dalam proses pembangunan desa dan laporan harus di lakukan dengan baik. Dalam tahap ini seluruh kegiatan yang telak dilaksanakan di kelompokan dan disusun dengan baik untuk di laporkan.

Pelaporan. Pelaporan keuangan desa yang dimaksud adalah tahap terakhir dari bentuk pengelolaan keuangan desa. Setelah semua proses telah selesai akan disusun dalam bentuk laporan keuangan dan kemudian akan di laporkan kepada pihak yang bersangkutan.

Aplikasi Sistem Keuangan Desa (SISKEUDES). Aplikasi Sistem Keuangan Desa (SISKEUDES) merupakan aplikasi yang di buat oleh BPKP untuk mmembantu pemerintah desa dalam melakukan pelaporan keuangan desa. Aplikasi ini sangat mudah untuk digunakan oleh pemerintah desa karena fitur yang tersedia sangatlah mudah untuk dipahami dan dimengerti. Dengan tampilan yang sederhana membuat aplikasi ini terlihat sangat sederhana namun sangat baik untuk digunakan. Bisa menggunakan jaringan internet dan juga tidak. Aplikasi ini dibuat sudah menyesuaikan dengan proses dan tahap laporan keuangan dan dokumen-dokumen yang ada hanya akan di input saja karena sudah tertata dengan baik.

\section{METODE PENELITIAN}

Jenis Penelitian. Penelitian ini adalah menggunakan penelitian deskritif dengan menggumpulkan data hasil wawancara dan dokumentasi yang diperoleh dari kantor Desa Suwaan Kecamatan Kalawat Kabupaten Minahasa Utara mengenai permasalahan penelitian. 
Tempat dan Waktu Penelitian. Lokasi penelitian bertempat di Kantor Desa Suwaan Jl. Raya Manado - Bitung Kecamatan Kalawat Kabupaten Minahasa Utara. Waktu pelaksanaan dimulai pada bulan Juli sampai Agustus 2018.

\section{Jenis, Sumber dan Metode Pengumpulan data}

Jenis data. Dalam penelitian ini, penulis menggunakan data kualitatif sebagai dasar untuk mengetahui bagaimana pelaksanaan Aplikasi Sistem Keuangan Desa (SISKEUDES) diterapkan di Desa Suwaan Kecamatan Kalawat Kabupaten Minahasa Utara.

Sumber data. Sumber data yang digunakan dalam penelitian ini adalah data primer.Dalam penelitian menggunakan data primer yaitu hasil wawancara dan dokumentasi secara langsung dengan pemerintah Desa Suwaan tentang penerapan Aplikasi SISKEUDES.

Metode Pengumpulan data. Mengadakan Tanya jawab langsung kepada pemerintah desa atau pihak yang terkait dalam instansi pemerintahan. Metode ini digunakan untuk memperoleh data tentang gambaran umum Desa Suwaan dan bagaimana penerapan Aplikasi Sistem Keuangan Desa di Desa Suwaan. Pertanyaan penelitian diperlihatkan pada Tabel 1.

Tabel 1. Pertanyaan Penelitian

\begin{tabular}{lll}
\hline \multicolumn{1}{c}{ No. } & \multicolumn{3}{c}{ Pertanyaan } & \multicolumn{1}{c}{ Partisipan } \\
\hline 1. & Bagaimana pelaksanaan Sistem Keuangan & Kepala Desa \\
& Desa di Desa Suwaan ? & \\
2. & $\begin{array}{l}\text { Faktor apa saja yang menjadi kendala } \\
\text { terhadap penerapan Sistem Keuangan Desa di }\end{array}$ & Sekretaris Desa \\
& $\begin{array}{l}\text { Desa Suwaan? } \\
\text { Manfaat apa saja yang diterima pemerintah }\end{array}$ & Kepala Desa \\
desa dengan adanya Sistem Keuangan Desa & Sekretaris Desa \\
ini? & & Kepala Urusan Pemerintahan \\
& & Desa \\
\hline
\end{tabular}

Metode Analisis. Dalam penelitian ini peneliti menggunakan metode analisis deskriptif. Yaitu suatu metode pembahasan permasalahan yang sifatnya menggunakan, menggambarkan dan membandingkan suatu data atau keadaan serta melukiskan dan menerangkan suatu keadaan sedemikian rupa sehingga dapat ditarik kesimpulan.

\section{HASIL PENELITIAN DAN PEMBAHASAN}

\subsection{Hasil Penelitian}

Prosedur Penggunaan Aplikasi Sistem Keuangan Desa di Desa Suwaan Kecamatan Kalawat Kabupaten Minahasa Utara. Penerapan Sistem Keuangan Desa sangat penting adanya karena membantu pemerintah desa dalam mengelola keuangan desa menjadi lebih efektif dan efisien. Di terapkan pada tahun 2017 proses penggunaan Aplikasi Sistem Keuangan Desa Suwaan sudah dilaksanakan secara terstruktur dan sesuai prosedur. Semua laporan keuangan yang sudah selesai akan melewati proses penginputan ke dalam Aplikasi Sistem Keuangan Desa. Penginputan dilakukan sekali sesuai dengan transaksitransaksi yang ada dan akan menghasilkan output berupa dokumen penatausahaan dan laporan-laporan yang sesuai dengan perundang-undangan. Dalam proses pelaksanaannya ada 4 tahap yang harus dilalui:

1. Tahap Perencanaan. Pemerintah Desa harus menetapkan RAB (Rancangan Anggaran Biaya), RAB adalah mengalokasikan biaya yang diperlukan untuk pembangunan desa, serta biaya lain yang berhubungan dengan proses keuangan. RAB dibuat oleh Kepala Desa dan Badan Permusyawaratan Desa.

2. Tahap Pelaksanaan. Tahap implementasi dari Anggaran Pendapatan dan Belanja Desa 
(APBDes) meliputi seluruh rangkaian kegiatan pelaksanaan. Dalam tahap ini semua yang menjadi dasar terjadinya proses pengadaan barang dan jasa, penyusunan buku kas dan lain-lain.

3. Tahap Penatausahaan. Merupakan proses pencatatan transaksi yang terjadi dalam satu tahun anggaran, kegiatan penatausahaan mempunyai fungsi untuk menatausahaakan proses yang telah terjadi dari tahap pelaksanaan dan perencanaan APBDes.

4. Tahap Pelaporan. Tahap untuk menyampaikan kegiatan yang telah dilakukan, hal-hal yang berhubungan dengan hasil pekerjaan yang telah dilakukan selama periode tertentu.

Setelah semua proses telah dilakukan secara bertahap dan telah diperiksa, selanjutnya yang akan dilakukan adalah proses penginputan ke dalam Aplikasi Sistem Keuangan Desa. Laporan-laporan yang akan diinput ke dalam sistem sebelumnya akan dibuat oleh pegawai desa yang bertugas, seperti Laporan Penatausahaan akan dibuat oleh Bendahara Desa. Setelah laporan-laporan selesai dibuat selanjutnya akan diberikan kepada Kepala Desa untuk diperiksa dan mendapatkan persetujuan untuk di input ke dalam sistem. Penginputan laporan ke dalam sistem hanya boleh dilakukan oleh Sekretaris Desa. Semua data yang akan diinput akan disesuaikan dengan sistem, data yang sudah di input ke dalam sistem sudah tidak bisa di ubah lagi, maka dari itu proses penginputan harus dilakukan dengan baik karena jika terdapat data yang salah atau tidak sesuai akan menjadi hambatan di kemudian hari terhadap proses pelaporan keuangan.

Kendala Terhadap Penerapan Aplikasi Sistem Keuangan Desa Di Desa Suwaan. Aplikasi Sistem Keuangan Desa merupakan salah satu bentuk inovasi sistem pelaporan keuangan desa yang mengedepankan aksesbilitas, serta efektif dan efisien waktu. Aplikasi ini dikembangkan BPKP agar desa-desa diseluruh indonesia mampu menciptakan laporan keuangan yang akuntabel dan mengurangi terjadinya korupsi yang kerap dilakukan oleh aparat desa karena kurangnya kontrol dari pusat. Adanya penerapan Sistem Keuangan Desa tersebut tentunya memberikan kelebihan maupun kelemahan bagi penggunanya. Kelebihan SISKEUDES memudahkan pemerintah desa dalam tata kelola keuangan, aplikasi ini juga bisa digunakan secara online maupun offline, dilengkapi dengan petunjuk pelaksanaan implementasi dan manual aplikasi sehingga dapat menciptakan laporan keuangan yang lebih akurat. Kelemahan dari aplikasi ini sering mengalami error pada saat proses penginputan dan juga data tidak ter input dengan baik ataupun halaman entri tidak muncul.

Pembahasan penerapan aplikasi sistem keuangan Desa di Desa Suwaan. Berdasarkan penelitian yang dilakukan bahwa penerapan Aplikasi Sistem Keuangan Desa di Desa Suwaan Kecamatan Kalawat Kabupaten Minahasa Utara sejauh ini sudah berjalan dengan baik. Prosedur-prosedur penggunaan SISKEUDES pun sudah dilakukan sesuai dengan peraturan yang berlaku. Menu-menu di Aplikasi Sistem Keuangan Desa pun dibuat dengan sedemikian rupa sesuai dengan prosedur Pengelolaan Keuangan Desa. Dimulai dari tahap Perencanaan, Pelaksanaan, Penatausahaan, dan Pelaporan. Laporan-laporan atas pelaksanaan 4 tahap tersebut selanjutnya akan dibuat oleh pegawai yang bertugas. Bendahara.

Desa memegang peranan yang sangat penting karena hampir semua laporan keuangan akan dibuat oleh Bendahara Desa. Setelah semua laporan telah selesai akan di serahkan kepada Kepala Desa untuk di periksa dalam tahap ini mengoreksi dan memverifikasi kembali segala kesalahan yang mungkin terjadi. Setelah di periksa laporan akan diserahkan kepada operator desa untuk di input. Dalam hal ini kualitas Sumber Daya Manusia (SDM) harus sangat di perhatikan karena dapat berdampak pada kualitas laporan keuangan yang akan di hasilkan. Penelitian terdahulu oleh Sulina, Wahyuni, Kurniawan (2017), mengatakan kualitas Sumber Daya Manusia sangat berpengaruh terhadap kualitas dari hasil laporan keuangan, dalam hal ini operator Sistem Keuangan Desa di Desa Suwaan adalah Sekretaris Desa Bapak 
Vecky Dungus. Kualitas SDM yang dimiliki sudah sangat baik karena Sekretaris Desa sudah berpengalaman dalam hal Sistem Informasi dalam mengaplikasikan komputer.

Dampak positif dari adanya Sistem Keuangan Desa menjadikan Pemerintah Desa lebih meningkatkan kinerja agar dapat menghasilkan laporan keuangan yang efektif dan efisien. Hal ini menunjukkan bahwa SISKEUDES juga berpengaruh terhadap kinerja Pemerintah Desa, hasil ini sesuai dengan tujuan dari diterapkannya SISKEUDES yaitu untuk membantu kerja Pemerintah Desa. Kesiapan dari Pemerintah Desa pun dapat dikatakan siap, karena terlihat dari segi SDM yang terpenuhi. Penggunaan Sistem Keuangan Desa tentunya tidak luput dari beberapa kendala seperti yang di katakan Kepala Desa bahwa masih ada beberapa laporan yang belum input ke sistem, hal ini mungkin terjadi karena SISKEUDES sering mengalami error, ada baiknya para pegawai berusaha untuk melakukan koordinasi antar pegawai dan pendamping desa untuk dapat memaksimalkan pekerjaan sehingga mampu mengatasi masalah yang terjadi.

\section{KESIMPULAN DAN SARAN}

\subsection{Kesimpulan}

Dari hasil penelitian yang telah di lakukan bahwa Penerapan Sistem Keuangan Desa di Desa Suwaan sudah berjalan dengan baik meskipun terdapat beberapa kendala yang di hadapi. Berdasarkan hasil pembahasan yang telah di dapatkansebelumnya maka dapat ditarik kesimpulan sebagai berikut :

1. Prosedur penggunaan Sistem Keuangan Keuangan Desa di Desa Suwaan dilakukan sesuai prosedur Pengelolaan Keuangan Desa yaitu Perencanaan, Pelaksanaan, Penatausahaan, dan Pelaporan.

2. Kesiapan Pemerintah Desa dalam melaksanakan Aplikasi Sistem Keuangan Desa sudah dapat dikatakan siap karena dari segi SDM yang sudah terpenuhi.

3. Manfaat dari Aplikasi Sistem Keuangan Desa menjadikan Pemerintah Desa bekerja lebih efektif dan efisien dalam menghasilkan Laporan Keuangan.

4. Kendala terhadap penerapan Aplikasi Sistem Keuangan Desa yaitu sering terjadi masalah error saat proses peng inputan.

5. Masih terdapat beberapa laporan yang belum terinput ke sistem dan masih menggunakan pelaporan secara manual.

\subsection{Saran}

Berdasarkan pada penelitian sebelumnya, maka saran antara lain :

1. Diharapkan Pemerintah Desa Suwaan dapat mempertahankan kinerja yang baik dalam proses Pengelolaan Keuangan Desa berbasis Aplikasi Sistem Keuangan Desa.

2. Mempertahankan kualitas Sumber Daya Manusia agar dapat mendukung proses Pengelolaan Keuangan Desa.

3. Memaksimalkan laporan-laporan yang belum terinput ke sistem agar tercipta kualitas Laporan Keuangan yang baik.

4. Lebih bersosialisasi dengan pemerintah setempat atau pendamping desa agar lebih meminimalisir terjadinya error pada Aplikasi Sistem Keuangan Desa.

\section{DAFTAR PUSTAKA}

Abdul Halim. 2013. Akuntansi Sektor Publik. Jakarta: Selemba Empat.

Anwar, M. 2012. Kontribusi Dan Peran Pengelolaan Keuangan Desa Untuk Mewujudkan Anggaran Pendapatan Dan Belanja Desa Yang Transparansi Dan Akuntabel (Survey Pada Perangkat Desa Di Kecamatan Ngaglik Sleman Yogyakarta.). Jurnal Akuntansi. Universitas Muhammadiyah Yogyakarta. 
Ardli, Z. 2017. Analisis Sistem Informasi Keuangan Desa Di Kecamatan Wonosari Klaten Berdasarkan Teori Kualitas Mc Call. Skripsi. Fakultas Sains Dan Teknologi. Universitas Islam Negeri Sunan Kalijaga. Yogyakarta

Atmaja, D. 2016. Analisis Pengelolaan Keuangan Dan Kekayaan Desa (studi kasus diDesa Plesungan Kecamatan Gondangrejo kabupaten karanganyar).E-jurnalkatalogis. ISSN 2302-2019. Volume 3. Univerisitas Muhammadiyah Surakarta.

Attatir, M. 2017. Analisis Kemanfaatan Perangkat Lunak Aplikasi Sistem Kkeuangan Desa (SISKEUDES) Dalam Pengelolaan Keuangan Desa (Studi Pada Kantor Pemerintahan Desa Kabupaten Kediri). Universitas Riau

Bachtiar, A dan M, Iskandar. 2013. Akuntansi Pemerintahan. Selemba Empat. Jakarta.

Badan Pendidikan Pelatihan Keuangan. 2015. Pengelolaan Keuangan Desa. www.bppk.kemenkeu.go.id. 27 Juli 2018. (22.00)

Badan Pengawasan Keuangan dan Pembangunan. 2016. Pengawalan Keuangan Desa Dengan Aplikasi Siskeudes. http://www.bpkp.go.id. 15 Maret 2018 (13.15)

Brata, A. 2017. Analisis Penerapan Sistem Keuangan Desa (SISKEUDES) Pada Kecamatan Sungai Raya Kabupaten Kubu Raya. Skripsi. Fakultas Ekonomi Dan Bisnis. Universitas Panca Bakti. Pontianak

Dissanayaka, DKK. 2015. "The Development Of Publikc Sector Accounting And Financial Reporting In Sri lanka”.

Sulina, I. G. A. 2017. Peranan Sistem Keuangan Desa (SISKEUDES) Terhadap Kinerja Pemerintah Desa (Studi Kasus Di Desa Kaba-Kaba Kecamatan Kediri Kabupaten Tabanan. Skripsi. Universitas Pendidikan Ganesha. Surakarta. Indonesia

Supriadi, E. 2015: Pertanggungjawaban Kepala Desa Dalam Pengelolaan Keuangan Desa Berdasarkan Undang-Undang Nomor 6 Tahun 2014 Tentang Desa. Skripsi. Universitas Mataram. Nusa Tenggara Barat.

Tanor. 2015. Analisis Laporan Keuangan Dalam Mengukur Kinerja Keuangan Pada PT.Bank Artha Graha International Tbk. Jurnal EMBA, 608-743.

Taufik, T. 2013. Pengelolaan Keuangan Desa Dalam Sistem Keuangan Negara Republik Indonesia. Jurnal Ekonomi.Jurusan Akuntansi Fakultas Ekonomi Universitas Riau.

Tinungki, A. 2014. Penerapan Laporan Keuangan Organisasi Nirlaba Berdasarkan PSAK No.45 Pada Panti Sosial Tresna Werdha Hana. Jurnal EMBA. Vol.2 Manado. Hal 716-840.

Tuti, A. 2017. Determinants of Village Financial Management and It's Implication Toward Accountability: Study on Village Governance in West Lombok Regency. Iinternational Journal. Universitas Mataram. Indonesia

Undang-Undang Negara Republik Indonesia Nomor 6 Tahun 2014 Tentang Desa. 15 Januari 2014. Lembaran Negara Nomor 5495. Jakarta

Widarnawati, W. 2018. Factors Affecting of Village Financial Management and It's Implications For Stakeholders Trust (Study on Villages in Central Lombok). International Journal. Universitas Mataram. Indonesia 